\title{
Studi Perbandingan Ekpektasi Biaya Total Antara Kasus Bakcorder dan Lost Sales pada Model Persediaan Probabilistik
}

\author{
Valeriana Lukitosari \\ Jurusan Matematika \\ FMIPA ITS \\ valeriana@matematika.its.ac.id
}

\begin{abstract}
Model persediaan probabilistik merupakan pengembangan dari model pengendalian persediaan deterministik untuk keadaan yang lebih realistik yaitu persediaan atas permintaan yang tidak menentu. Masalah penting yang muncul dalam sistem pengendalian persediaan adalah apa yang terjadi pada pesanan konsumen, ketika barang yang dipesan untuk sementara waktu tidak tersedia. Hal ini menyebabkan terjadinya kasus backorder dan lost sales. Dalam paper ini akan dianalisa perbedaan Ekpektasi Biaya Total antara kasus bakcorder dan lost sales.
\end{abstract}

Kata Kunci: model persediaan probabulistik, backorder, lost sales

\section{Pendahuluan}

Persediaan berkaitan dengan penyimpanan persediaan barang yang cukup. Terlalu sedikit dapat menyebabkan interupsi yang mahal pada operasi sistem yang bersangkutan, terlalu banyak dapat merusak daya saing dan profitabilitas perusa- 
haan. Sehingga perlu penanganan persediaan dalam meminimumkan dampaknya yang merugikan dengan menemukan titik tengah yang menyenangkan diantara kedua kasus tersebut. Adanya persediaan dalam perusahaan merupakan hal sulit untuk dihindarkan. Permintaan akan material atau yang lebih sering disebut dengan barang yang datang pada suatu perusahaan tidak selalu dapat dengan segera dipenuhi pada saat permintaan itu tiba, hal ini dikarenakan untuk mengadakan barang dibutuhkan waktu tunggu (lead time) baik untuk proses pembuatan barang tersebut maupun untuk mendatangkannya. Mekanisme pemenuhan atas permintaan. Permintaan terhadap suatu barang tidak dapat dipenuhi seketika bila barang tersebut tidak tersedia sebelumnya. Untuk menyiapkan barang ini diperlukan waktu untuk pembuatan dan pengiriman, maka adanya persediaan merupakan hal yang sulit dihindarkan. Selain itu terdapat keinginan untuk meredam ketidakpastian. Ketidakpastian terjadi akibat: permintaan yang bervariasi dan tidak pasti dalam jumlah maupun waktu kedatangan, waktu pembuatan yang cenderung tidak konstan antara satu produk dengan produk berikutnya, waktu tunggu yang cenderung tidak pasti karena banyak faktor yang tak dapat dikendalikan. Ketidakpastian ini dapat diredam dengan mengadakan persediaan. Demikian juga terdapat keinginan melakukan spekulasi yang bertujuan untuk mendapatkan keuntungan besar dari kenaikan harga di masa mendatang.

\section{Model Pengendalian Persediaan Probabilistik}

Dalam model persediaan probabilistik diasumsikan tingkat kebutuhan dimasa mendatang dan waktu tunggu tidak diketahui dengan pasti (variable), tetapi dapat diketahui melalui distribusi dari data masa lalu. Pada model ini juga memperhitungkan adanya resiko dan ketidakpastian dalam perumusannya.

Ada 2 metode dasar pengendalian persediaan yang bersifat probabilistik, yaitu sebagai berikut:

1. Metode $\mathrm{P}$, yang menganut aturan bahwa saat pemesanan bersifat regular mengikuti suatu periode yang tetap (mingguan, bulanan,dsb), sedangkan kuantitas pemesanan akan berulang-ulang.

2. Metode Q, yang menganut aturan bahwa jumlah ukuran pemesanan (kuantitas pemesanan) selalu tetap untuk setiap kali pesan, sehingga saat pemesanan dilakukan akan bervariasi

Keuntungan menggunakan model pengendalian persediaan probabilistik adalah sebagai berikut: 
1. Pada kenyataannya, permintaan suatu barang selalu berfluktuasi (tidak diketahui dengan pasti), sehingga pengendalian persediaan probabilistik lebih menguntungkan.

2. Model ini dapat dipakai untuk waktu tunggu yang tidak konstan (variable)

3. Kekurangan barang (stockout) diperbolehkan karena ada persediaan pengamannya (safety stock).

Biaya total persediaan pertahun untuk model persediaan probabilistik adalah sebagai berikut:

Total annual cost $=$ purchase cost + order cost + holding cost + stockout cost atau

$$
T C=P_{c}+O_{c}+H_{c}+S_{c}
$$

dimana:

$P_{c}$ : biaya pembelian

$O_{c}$ : biaya pemesanan

$H_{c}$ : biaya penyimpanan

$S_{c}$ : biaya kekurangan persediaan

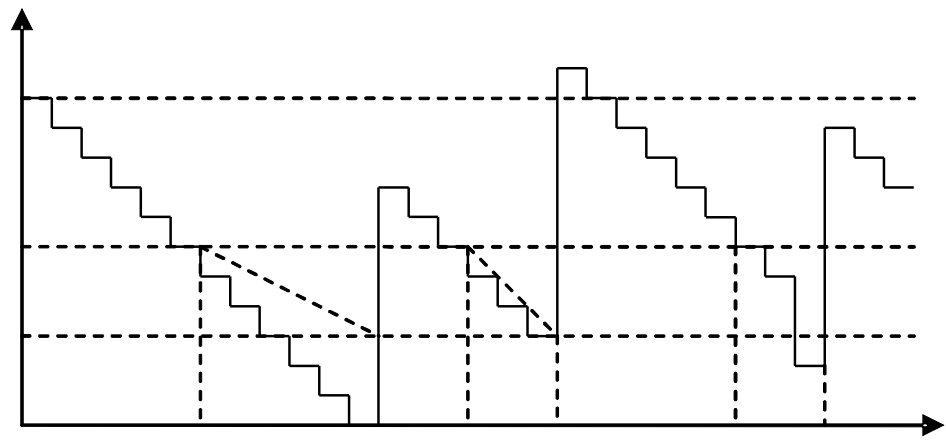

Gambar 1: . Model Persediaan Probabilistik

Beberapa hal yang perlu diperhatikan dalam model persediaan probabilistik pada kasus backorder dan lost sales adalah sebagai berikut:

1. Distribusi permintaan

Jika permintaan (demand) bersifat probabilistik maka diperlukan minimasi ekspektasi biaya persediaan. Jika distribusi permintaan kontinu maka minimasi ekspektasi biaya diperoleh dengan menurunkan ekspektasi biaya terhadap variabel tertentu dan kemudian diberi harga nol. 
Untuk mendeskripsikan permintaan yang berdistribusi digunakan dua parameter yaitu rata-rata (mean) dan standar deviasi. Perhitungan mean dan standar deviasi untuk distribusi kontinu adalah sebagai berikut:

$$
\begin{aligned}
\bar{M} & =\int_{0}^{\infty} M f(M) d M \\
\sigma^{2} & =\int_{0}^{\infty}(M-\bar{M})^{2} f(M) d M
\end{aligned}
$$

Tabel 1: Perhitungan Statistik

\begin{tabular}{|c|c|}
\hline Variabel & Distribusi Kontinu \\
\hline$M$ & $\int_{0}^{\infty} M f(M) d M$ \\
\hline$\sigma^{2}$ & $\int_{0}^{\infty}(M-\bar{M})^{2} f(M) d M$ \\
\hline$P(M>B)$ & $\int_{B}^{\infty} f(M) d M$ \\
\hline$E(M>B)$ & $\int_{0}^{\infty}(M-B) f(M) d M$ \\
\hline
\end{tabular}

dengan:

$M \quad$ : permintaan selama waktu tunggu dalam unit

$\sigma \quad$ : standar deviasi dari permintaan selama waktu tunggu

$f(M) \quad$ : fungsi kepadatan probabilitas dari permintaan selama waktu tunggu

$B \quad$ : titik pemesanan kembali

$P(M>B)$ : probabilitas kekurangan persediaan

$E(M>B)$ : ekspektasi kekurangan persediaan selama waktu tunggu dalam unit

2. Safety stock / persediaan pengaman

Persediaan pengaman adalah suatu persediaan yang diadakan untuk menjaga kemungkinan terjadinya tingkat kebutuhan yang lebih tinggi dari pada perhitungan dan kemungkinan terjadinya keterlambatan pengiriman barang. Semakin besar tingkat safety stock suatu perusahaan maka mengurangi resiko kehabisan persediaan semakin kecil, tetapi biaya penyimpanan semakin besar karena jumlah total persediaan meningkat. Oleh karena itu perlu ditentukan besarnya persediaan pengaman yang dapat meminimasi biaya total persediaan. 


\subsection{Backorder}

Dalam kasus backorder tidak terjadi kehilangan penjualan, tetapi konsumen menunggu pesanan mendatang karena persediaan tidak tersedia. Sehingga ekspetasi persediaan pengaman didefinisikan sebagai berikut:

$$
\begin{aligned}
S & =\int_{0}^{\infty}(B-M) f(M) d M \\
& =\int_{0}^{\infty} B f(M) d M-\int_{0}^{\infty} M f(M) d M \\
& =B-\bar{M}
\end{aligned}
$$

dan ekspektasi jumlah backorder per waktu tunggu didefinisikan

$$
E(M>B)=\int_{0}^{\infty}(M-B) f(M) d M
$$

\subsection{Lost Sales}

Pada kasus lost sales, semua kekurangan persediaan hilang dan tidak terpenuhi. Sehingga ekspetasi persediaan pengaman dapat dituliskan sebagai berikut:

$$
\begin{aligned}
S & =\int_{0}^{B}(B-M) f(M) d M \\
& =\int_{0}^{\infty}(B-M) f(M) d M-\int_{B}^{\infty}(B-M) f(M) d M \\
& =B \int_{0}^{\infty} f(M) d M-\int_{0}^{\infty} M f(M) d M-\int_{B}^{\infty}(B-M) f(M) d M \\
& =B-\bar{M}-\int_{B}^{\infty}(B-M) f(M) d M
\end{aligned}
$$

Ekspektasi jumlah lost sales per waktu tunggu didefinisikan

$$
E(M>B)=\int_{0}^{\infty}(M-B) f(M) d M
$$




\section{Ekspektasi Biaya Total Persediaan Pertahun Pada Kasus Backorder dan Lost Sales}

Pada model persediaan probabilistik diketahui bahwa biaya total persediaan pertahun seperti pada Persamaan 1, sehingga

\section{Biaya pembelian barang:}

Pada model persediaan probabilistik, biaya pembelian sama dengan pada model persediaan deterministik yaitu biaya pembelian per unit dikalikan dengan rata-rata permintaan pertahun dalam unit, sehingga dapat dituliskan sebagai berikut:

$$
P_{c}=P \times R
$$

dengan:

$P$ : biaya pembelian barang

$R$ : permintaan per tahun dalam unit

\section{Biaya pemesanan barang:}

Biaya pemesanan pada model persediaan probabilistik sama dengan biaya pemesanan pada pada model persediaan deterministik yaitu diperoleh dari biaya pemesanan per sekali pesan dikalikan dengan jumlah pesanan pertahun $(R / Q)$, dan dituliskan sebagai berikut:

$$
O_{c}=C \times \frac{R}{Q}
$$

dengan:

$C \quad$ : biaya pemesanan persekali pesan

$Q \quad$ : kuantitas pemesanan barang dalam unit

$R / Q$ : jumlah pemesanan per tahun

\section{Biaya penyimpanan barang:}

Pada kasus backorder biaya penyimpanan diperlukan untuk barang persediaan dan untuk persediaan pengaman (safety stock), sehingga biaya penyimpanan barang adalah sebagai berikut:

$$
H_{c}=\left(H \times \frac{Q}{2}\right)+(H \times S)
$$

dengan:

$H \quad$ : biaya penyimpanan barang per unit per tahun

$Q / 2$ : rata-rata persediaan barang per tahun

$S \quad$ : persediaan pengaman dalam unit 
Dengan mensubstitusikan Persamaan 2 ke Persamaan 7 maka didapatkan biaya total penyimpanan barang untuk kasus backorder sebagai berikut:

$$
H_{c}=\left(H \times \frac{Q}{2}+B-\bar{M}\right)
$$

dimana:

$\bar{M}$ : rata-rata permintaan dalam waktu tunggu dalam unit

\section{Biaya kekurangan persediaan:}

Pada kasus backorder tidak terjadi kehilangan penjualan, karena konsumen mau menunggu sampai pesanan mendatang tiba jika persediaan tidak tersedia, dan ekspetasi jumlah backorder per waktu tunggu adalah seperti pada Persamaan 2.2, sehingga biaya kekurangan persediaan dapat diperoleh dari biaya backorder per unit dikalikan dengan jumlah pemesanan per tahun dan dikalikan dengan ekspektasi jumlah backorder per waktu tunggu dan dapat dituliskan sebagai berikut:

$$
S_{c}=A \times \frac{R}{Q} \times E(M>B)
$$

dengan:

$A$ : biaya backorder per unit

Dengan mensubstitusikan Persamaan 5, 6, 8 dan 9 ke Persamaan 1, maka akan diperoleh ekspektasi biaya total persediaan pada kasus backorder untuk satu jenis barang, yaitu sebagai berikut:

$$
T C(Q)=P R+\frac{R}{Q}(C+A E(M>B))+H\left(\frac{Q}{2}+B-\bar{M}\right)
$$

Sehingga dari Persamaan 10 dapat dikembangkan untuk ekspektasi biaya total persediaan pada kasus backorder untuk beberapa jenis barang, yaitu sebagai berikut:

$T C\left(Q_{1}, \cdots, Q_{n}\right)=\sum_{i=1}^{n}\left[P_{i} R_{i}+\frac{R_{i}}{Q_{i}}\left(C_{i}+A_{i} E\left(M_{i}>B_{i}\right)\right)+H_{i}\left(\frac{Q_{i}}{2}+B_{i}-\overline{M_{i}}\right)\right]$

dengan:

$n \quad$ : jumlah barang

$T C\left(Q_{1}, \cdots, Q_{n}\right)$ : total biaya untuk beberapa jenis barang per tahun

$P_{i} \quad:$ biaya pembelian barang ke-i per unit 


$\begin{array}{ll}R_{i} & : \text { permintaan per tahun barang ke-i dalam unit } \\ Q_{i} & : \text { kuantitas pemesanan barang ke-i dalam unit } \\ C_{i} & : \text { biaya pemesanan barang ke-i per sekali pesan } \\ H_{i} & : \text { biaya penyimpanan barang ke-i per unit per tahun } \\ A_{i} & : \text { biaya backorder barang ke-i per unit } \\ M_{i} & : \text { permintaan dalam waktu tunggu barang ke-i dalam unit } \\ \bar{M}_{i} & : \text { rata-rata } M_{i} \\ B_{i} & \text { titik pemesanan kembali barang ke-i } \\ E\left(M_{i}>B_{i}\right) & : \text { ekspetasi jumlah backorder barang ke-i per waktu tunggu }\end{array}$

Pada kasus lost sales, biaya penyimpanan barang adalah sebagai berikut:

$$
H_{c}=H\left(\frac{Q}{2}+B-\bar{M}-\int_{B}^{\infty}(B-M) f(M) d M\right)
$$

Jadi ekspektasi biaya total persediaan untuk kasus lost sales untuk satu jenis barang adalah sebagai berikut:

$$
T C(Q)=P R+\frac{R}{Q}(C+G E(M>B))+H\left(\frac{Q}{2}+B-\bar{M}+E(M>B)\right)
$$

Sehingga ekspektasi biaya total persediaan pada kasus lost sales untuk beberapa jenis barang dapat dituliskan sebagai berikut:

$$
T C\left(Q_{1}, \cdots, Q_{n}\right)=\sum_{i=1}^{n}\left[\begin{array}{l}
P_{i} R_{i}+\frac{R_{i}}{Q_{i}}\left(C_{i}+G_{i} E\left(M_{i}>B_{i}\right)\right) \\
+H_{i}\left(\frac{Q_{i}}{2}+B_{i}-\overline{M_{i}}+E\left(M_{i}>B_{i}\right)\right)
\end{array}\right]
$$

dimana:

$G_{i}$ : biaya lost sales barang ke-i per unit

\section{Penutup}

Dari pembahasan diatas dapat disimpulkan bahwa dalam model persediaan, ekpektasi biaya total pada kasus backorder dan lost sales berkaitan dengan perbedaan pada persediaan pengamannya

\section{References}

[1] Cohen, M.A, Analysis of Single Critical Number Ordering for Inventories, Operations Research, 1978. 
[2] Hicks, Philip E, Industrial Engineering and Management: A New Perspective, Second Edition, McGraw-Hill, Inc., New York, 1994.

[3] Lapin, Lawrence, Quantitative Method for Business Decisions, 6th , Duxbury Press, 1994.

[4] Silver, Edward A., Peterson,Rein, (1985), Decision System for Inventory Management and Production Planning, Second Edition, John Wiley \& Sons, New York.

[5] Taha, Hamdy, Riset Operasi, Suatu pengantar, jilid 2, Binarupa Aksara, 1997.

[6] Wagner, H.M, Principles of Operation research with Aplications to Managerial Decision, Fourth Edition, Prentice-Hall, Inc., New Jersey, 1995. 